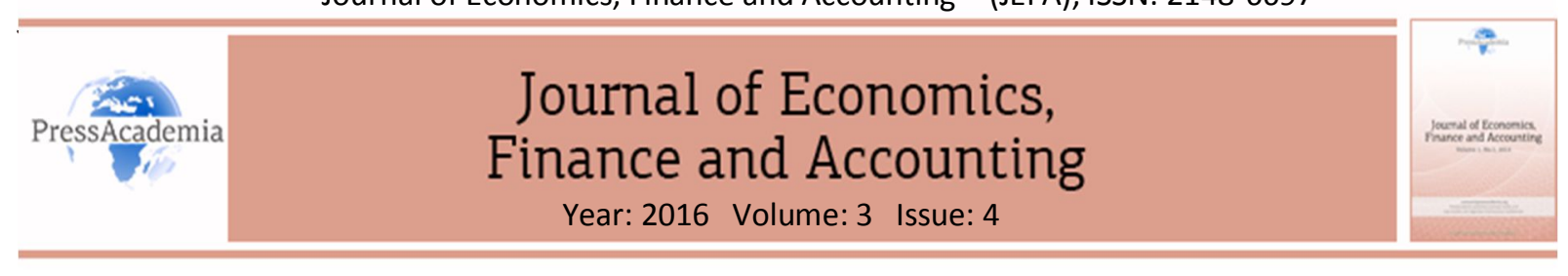

\title{
THE EFFECTS OF SALES OF THE NON-PERFORMING LOANS TO ASSET MANAGEMENT COMPANIES ON BANK EFFICIENCY
}

\section{DOI: 10.17261/Pressacademia.2016.348}

\author{
Ozge Sezgin Alp ${ }^{1}$, Senol Babuscu ${ }^{2}$, Onur Sunal ${ }^{3}$, Adalet Hazar ${ }^{4}$ \\ ${ }^{1}$ Başkent Üniversitesi, osezgin@baskent.edu.tr \\ ${ }^{2}$ Başkent Üniversitesi, babuscu@baskent.edu.tr \\ ${ }^{3}$ Başkent Üniversitesi, osunal@ baskent.edu.tr \\ ${ }^{4}$ Başkent Üniversitesi, ahazar@baskent.edu.tr
}

\begin{abstract}
Commercial banks have an important role in fund transfer mechanism besides they aim to operate efficiently while bearing various risks. Operational efficiency depends on risk minimisation. Banks tend to sell their non-performing loans (NPL) to asset management companies to lower their NPL ratios which are important indicators of asset qualities. In this study the effect of change in ratio during $2008-2015$ period on bank efficieny is investigated. Directional distance function methodology is used to evaluate bank efficiency. Employees, assets and deposits are taken as input, ratio is taken as desirable output, loan and portfolio risks are taken as undesirable output. As a result it's found that efficient banks aren't effected form the sales of NPL while the efficiency of some non-efficient banks are positively affected.
\end{abstract}

Keywords: Banking, non-performing loans, efficiency, directional distance function risk.

JEL Classification: G21,G23,G29.

\section{BANKALARIN TAKIPTEKI KREDILERINI VARLIK YÖNETIM ŞIRKETLERINE SATIŞLARININ VERIMLILIĞE ETKISI}

\section{ÖZET}

Bankalar, finansal piyasada fon transferinde önemli rol üstlenirken bir taraftan etkin şekilde çalışmaya özen göstermekte, diğer taraftan da bazı riskleri üstlenmektedir. Etkin çalışabilmenin ön koşullarından birisi bu risklerini minimize etmektir. Bankalar, en önemli aktif kalitesi göstergelerinden biri olan Takipteki Krediler (Brüt) / Toplam Krediler rasyosunu düşürmek amacıyla takipteki kredilerini Varlık Yönetim Şirketlerine satmaktadır. Bu çalışmada 2008-2015 döneminde satış öncesi ve sonrası farklılaşan söz konusu rasyodaki değişikliklerin verimliliğe etkisi çalışanlar, varlıklar ve mevduatların girdi, NPL rasyosunun arzulanan çıktı, kredi ve portföy risklerinin arzulanmayan çıktı olarak ele alındığı Uzaklık Yönlü Fonksiyon Yaklaşımı kullanılarak araştırılmıştır. Sonuç olarak, etkin çıkan bankaların etkinliğinin takipteki kredilerin satışından etkilenmediği, etkin çalışmayan bazı bankaların etkinliğinde ise iyileşmeye neden olduğu görülmüştür.

Anahtar Kelimeler: Bankacılık, takipteki krediler, etkinlik, uzaklık yönlü fonksiyon, risk. JEL Sınıflandırması: G21,G23,G29. 


\section{GiRiş}

Ülkemizde bankacılık sektörü finansal piyasanın önemli bölümünü oluşturmaktadır. Bankacılık sektörünün finansal piyasa üzerinde etkisi düşünüldüğünde sektörün etkin çalışıp çalışmadığının değerlendirilmesine yönelik çalışmalar yapılması zorunlu hale gelmiştir.

Gelişen piyasalar ile birlikte, finansal piyasanın fon aracılı̆ında önemli rol üstlenen bankalar, bu faaliyetlerini yerine getirirken doğal olarak bazı riskleri de üstlenmektedir. Bankaların temel olarak üstlendikleri riskler kredi riski, piyasa riski ve operasyonel risk olarak gruplandırılmaktadır. Piyasa riski bünyesinde faiz, kur ve likidite risklerini içermektedir.

Bankaların yapmış oldukları işlemlere bağlı olarak finansal tablolarında üstlendikleri risklerin ağırlığı değişmektedir. Türk bankacılık sektörü açısından genelleme yapıldığında toplam riskler içinde en büyük ağırlık kredi riskine aittir. Nitekim 2008-2015 dönemine ilişkin hesaplanan yıllık bazdaki risklerin toplam içindeki dağılımı incelendiğinde kredi riskinin \%82,6-\%90,2 aralığında olduğu görülmektedir.

Tablo 1: Sermaye Yeterliliği Rasyosuna Esas Risklerin Toplam Riskler İçinde Oransal Dağılımı

\begin{tabular}{|c|c|c|c|c|}
\hline Yıllar & Kredi Riski & Piyasa Riski & Ops. Risk & Toplam Risk \\
\hline 2008 & 84,5 & 3,8 & 11,7 & 100,0 \\
\hline 2009 & 82,6 & 4,6 & 12,7 & 100,0 \\
\hline 2010 & 83,5 & 4,7 & 11,8 & 100,0 \\
\hline 2011 & 86,0 & 4,1 & 9,9 & 100,0 \\
\hline 2012 & 88,9 & 2,1 & 9,1 & 100,0 \\
\hline 2013 & 90,0 & 2,6 & 7,4 & 100,0 \\
\hline 2014 & 90,2 & 2,5 & 7,4 & 100,0 \\
\hline 2015 & 90,1 & 2,8 & 7,1 & 100,0 \\
\hline
\end{tabular}

Kaynak:https://www.tbb.org.tr/tr/bankacilik/banka-ve-sektor-bilgileri/istatistiki-raporlar/59 sayfasındaki verilerden tarafımızca derleme yapılarak oransal hesaplama yapılmıştır.

Bankaların finansal tablolarında yer alan bu risklerini azaltmaya yönelik çeşitli önlemleri bulunmaktadır. Her önleme rağmen hala yüksek görünen risk olması durumunda son yıllarda bankaların sıklıkla başvurduğu yöntemlerden birisi takipteki kredi portföyünden Varlık Yönetim Şirketlerine (VYŞ) satış olmaktadır.

Ülkemizde Varlık Yönetim Şirketleri ilk olarak 2004 yılında takipteki kredilerin Tasarruf Mevduatı Sigorta Fonu (TMSF)'ndan satın alınmasında rol oynamıştır. Daha sonrasında gerek TMSF gerekse çeşitli bankalar tarafından yapılan satışlarda Varlık Yönetim Şirketleri alıcı olarak fonksiyonunu sürdürmüştür.

Bankaların VYŞ'lere satışları 2008 yılından itibaren yoğun olarak başlamıştır. Bankaların bu satışlar sonrasında doğal olarak finansal tablolarında yer alan aktif kalitesinin en önemli göstergelerinden birisi olan Takipteki Krediler (Brüt) / Toplam Krediler rasyosunda bir iyileşme gerçekleşmiştir.

Takipteki kredilerinden varlık yönetim şirketlerine satış yapan çok sayıda bankanın rasyosunda, satış öncesine göre satış sonrasında düşüş yaşanmıştır. Çeşitli analizlerde finansal tablo verileri dikkate alındığı için, analiz yapan taraflar açısından da asıl veriler bu kapsamda satış sonrası veriler olmaktadır.

Bir bankanın etkin çalışıp çalışmadığına ilişkin incelemelerde, genellikle mevcut personel, varlık ve mevduatını kullanarak maksimum kredi ve portföy üretebilen bankalar etkin olarak kabul edilmektedir. Ancak, temel olarak bankaların etkin ve verimli çalışıp çalışmadıkları analiz edilirken, faaliyetleri sırasında üstlendikleri riskleri de bir taraftan minimize etmeleri beklenmektedir. Bu durumda, etkin bir banka aynı zamanda kredi ve portföy riskleri ile Takipteki Krediler (Brüt) / Toplam Krediler rasyosunu minimize edebilen banka olarak tanımlanabilir.

Özetle, bu çalışmada bankaların etkin çalışıp çalışmadıklarını değerlendirirken mevcut personel, varlık ve mevduatını kullanarak kredi ve portföylerini artırıp kredi ve piyasa risklerini belirli bir limitte tutup tutamadıklarını değerlendirirken, esas olarak önemli risk göstergelerinden birisi olan Takipteki Krediler (Brüt) / Toplam Krediler rasyosunun etkinliğe yansıması analiz edilmektedir. 
Bu kapsamda, çalışmada öncelikle benzer alanda daha önce yapılan çalışmalara değinilmiş ve çalışma kapsamına alınacak bankaların tanımlaması yapılmıştır. Daha sonra, analizin sağlıklı yapılabilmesi amacı ile veri seti homojen hale getirilmiştir. Çalışmanın, Bulgular ve Tartışma kısmında ise Varlık Yönetim Şirketleri'ne tahsil yeteneği düşük finansal varlıklarının satışını yapan bankalarda, söz konusu satış işlemlerinin bankaların etkinlik düzeylerinde bir iyileşmeye yol açıp açmadığı tartışılmıştır.

\section{LITERATÜR TARAMASI}

Dünya ülkeleri incelendiğinde kamu tarafından varlık yönetimi konusunda uzmanlaşmış şirketler kurulması yaygın bir uygulamadır (Mesut, 2001). Ancak, ülkemizde yaşanan Kasım 2000 ve Şubat 2001 krizleri ile birlikte krizin etkilerini azaltmak amacı ile VYŞ gündeme gelmiştir (Küçükbay ve Demirhan, 2003). Bu şirketler bankacılık sisteminin sorunlu aktiflerini devralma görevini üstlenmektedir.

Giriş kısmında da belirtildiği üzere bankaların riskleri arasında en büyük payı alan kredi riskidir. VYŞ kurulması ile birlikte bankalar takipteki kredilerin bir kısmını varlık yönetim şirketlerine satarak, alacaklarını nakde çevirebilme olanağını elde ederken, aynı zamanda, takipteki kredilerini elden çıkartarak finansal tablolarında görünen kredi risklerini azaltmayı da hedeflemektedir.

Gelişen bir piyasa olan ülkemizde varlık yönetim şirketleri ile ilgili sınırlı sayıda çalışma bulunmaktadır.

Mesut (2001) çalışmasında çeşitli ülkelerde "varlık yönetimi ve tasfiyesi sistemleri" kurulurken ve işletilirken göz önünde tutulan amaç ve ilkelere dikkat çekmektedir. Çalışmada aynı zamanda sistemlerin başarı şansını etkileyen faktörler ortaya konulmaktadır.

Selimler (2006) çalışmasında Türkiye'de sorunlu kredilerin varlık yönetim şirketlerine tasfiyesi konusunu incelemiş, seçilmiş bazı ülkelerde ve Türkiye'deki VYş uygulamasını değerlendirilmiştir. Türkiye'deki varlık yönetim şirketlerinin yapılanması konusunda ise bazı öneriler ileri sürmüştür.

Babuşcu ve Hazar (2013), bankaların takipteki kredilerini varlık yönetim şirketlerine satışları ile ilgili yaptıkları çalışmada, yapılan satışlar, bu satışların fiyatlamasına ilişkin model önerisinde bulunmuşlardır. Aynı zamanda, bu çalışmada, yapılacak satışların bankaların verimliliğine katkı sağlayacak seviyede olabilmesine ilişkin dikkate alınması gereken temel kriterler vurgulanmıştır.

Gör ve Tekin (2014), çalışmalarında varlık yönetim şirketlerinin, Türkiye ekonomisine ve bankacılık sektörüne katkılarını incelemiştir. Sonuç olarak, bu çalışma bankaların takipteki kredilerini temizleyerek finansal piyasaları düzenlemek konusunda VYŞ’lerin bir etken olduğunu belirlemiştir.

Bankacılık sektörü finansal piyasanın önemli bir kısmını oluşturmaktadır. Bu nedenle, sektörün etkin çalışması Türkiye ekonomisi açısından büyük önem arz etmektedir. Bu amaçla son yıllarda yapılan çalışmalara, Demir, Mahmud ve Babuşcu (2004), Budak (2011), Er ve Uysal (2012), Akbalık ve Sırma (2013), Yayar ve Karaca (2014), Torun ve Özdemir (2015) tarafından yapılanlar örnek verilebilir.

Demir, Mahmud ve Babuşcu (2005), teknik verimlilik açısından 23 banka verileri ile yaptıkları çalışmalarında, etkinlik açısından kredi kalitesi ile hacmi, banka sahipliği ve karlılığın önemli olduğu sonucuna ulaşırken verimlilik artırmak amacı ile birleşme ve özelleştirmelerin teşvikinin üzerinde durmuşlardır.

Budak (2011), bankaların, şube sayısı, personel sayısı ve faiz ve faiz dışı giderler toplamı girdilerini etkin kullanarak toplam mevduat, toplam krediler, faiz ve faiz dışı gelirler toplamı ve net kar çıktılarını en iyi şekilde üretip üretemediklerini Veri Zarflama Analizi ile değerlendirmiştir. Çalışmada, 2008, 2009 ve 2010 yıllarında faaliyet gösteren ticari bankaların etkinlik değerlerinin hesaplanması amaçlanmıştır.

Er ve Uysal (2012) çalışmalarında, Türkiye'de faaliyet gösteren katılım bankaları ve ticari bankaların etkinlik düzeylerini 2005-2010 dönemi için karşılaştırmalı olarak analiz etmiştir. Bu çalışmada, etkinlik ölçümünde ölçeğe göre sabit getiri (CCR) ve ölçeğe göre değişken getiri (BCC) varsayımları altında girdi odaklı Veri Zarflama Analizi (VZA) kullanılmıştır. Veri Zarflama Analizinde personel sayıları, sermaye ve aktifler girdi olarak alınırken çıktı olarak toplam mevduat miktarı, toplam kredi miktarı ve net kar kullanılmıştır.

Akbalık ve Sırma (2013), çalışmalarında 2001 krizi sonrası Türk Bankacılık sektörüne satın alma ve ortaklık şeklinde dahil olan yabancı sermayeli bankaların sistem içindeki faaliyet etkinliğini incelemiştir. Etkinlik 
incelemesinde mevduat ve faaliyet giderleri girdi olarak, krediler ve faaliyet gelirleri ise çıktı olarak kullanılmıştır.

Yayar ve Karaca (2014), çalışmalarında 2009-2011 döneminde Türkiye'deki piyasa yapıcı bankaların etkinliğini Veri Zarflama Analizi ile ölçmüşler ve bankaların verimlilik puanlarını etkileyecek faktörler Tobit Regresyon Analizi ile tespit edilmiştir. Bankaların etkinliğini ölçmek için; Toplam Aktifler, Toplam Özkaynak, Çalışan Sayısı ve Şube Sayısı girdi değişkeni olarak kullanılmış ve Toplam Krediler, Toplam Mevduat ve Net Kar / Zarar çıktı değişkenleri olarak kullanılmıştır.

Torun ve Özdemir (2015), finansal krizin yaşandığı ve aşırı para arzının olduğu 2008-2013 yılları arasında Türkiye' de faaliyet gösteren mevduat bankalarının etkinliklerini Veri Zarflama Analizi (VZA) yöntemi ile ölçmüş ve incelemiştir.

Literatürdeki çalışmalardan da görüleceği üzere ülkemizde bankaların etkinliği ile ilgili yapılan çalışmalar genellikle belirli başlı girdiler ile en iyi çıktıları üretebilen bankaları etkin olarak değerlendiren standart Veri Zarflama Analizi yöntemi kullanılmaktadır. Ancak bankalar bu çıktılarını üstlenirken aynı zamanda belirli riskleri de üzerlerine almaktadırlar. Etkinlik ölçümünde risklerin etkisinin değerlendirmeye katan sınırlı sayıda çalışma bulunmaktadır (örn: Işık ve Hasan (2002), Özhan-Günay (2012), Eken ve Kale (2013), Sezgin-Alp ve Hazar (2015)).

Bu çalışmanın diğer çalışmalardan farkı, bir taraftan etkinlik ölçümüne risklerin etkisini katarken, aynı zamanda bankaların çeşitli şekillerde finansal tablolarına yansıttıkları risklere ilişkin yaptıkları iyileştirmelerin etkinliğe katkı sağlayıp sağlamadığını araştırmaktır.

\section{VERI SETI VE METODOLOJi}

\subsection{Veri Seti}

Çalışmada kullanılan veriler belirlenirken, öncelikle veri setini oluşturan bankaların kendi aralarında homojen olmasına dikkat edilmiştir. Bu nedenle, çalışmada analiz kapsamına mevduat toplayan bankalar ile Türkiye'de kurulu bulunan bankalar dahil edilmiş, kalkınma ve yatırım bankaları, yurtdışı bankalardan sadece şubeleri Türkiye'de faaliyette bulunan bankalar ile Birleşik Fon Bankası dahil edilmemiştir.

Bu çerçevede yukarıdaki özelliklere göre oluşturulan banka sayısı toplam 23 adettir. 23 bankaya ait personel, varlık, mevduat, kredi, portföy, kredi riski, piyasa riski ve Takipteki Krediler (Brüt) / Toplam Krediler rasyosu başlıklarına ilişkin 2008-2015 yılları arası için veriler veriler Türkiye Bankalar Birliği sayfasından elde edilmiştir.

Analiz kapsamındaki bankalardan 16 adedi takipteki kredilerinden 2008-2015 dönemi içinde satış yapmıştır.

3 adet kamu bankası hiç satış yapmamış olup, gerekçe olarak da kamu bankalarının satış yapabilmesi için ayrı bir yasal düzenlemeye ihtiyaç olduğunu ifade etmektedirler.

Satış yapmayan bankalar grubunda yer alan diğer 4 bankadan:

- Deutsche Bank tek şubeli banka olup aynı zamanda takipte kredisi bulunmamaktadır.

- Citibank bireysel kredilerden çıkmış, çok sayıda şubesini satarak küçülmüş bir bankadır.

- Arap Türk Bankası 7 şubeli küçük ölçekli bir banka olup, aynı zamanda hisselerinin \% 62,37'lik bölümü TMSF tarafından bu dönemde yönetilme kararı alınmış bir bankadır.

- Turkish Bank'ın ise 2011 yılı sonrasında takipteki kredi rasyosunda çok ciddi bir düşüş yaşanmış olup, bu nedenle bu tür bir satış ihtiyacının doğmadığı düşünülmektedir.

Bu çerçevede Türk Bankacılık Sektöründe faaliyette bulunan ticari bankalardan kamu bankaları hariç çoğunluğu, belirli dönemlerde takipteki kredilerini finansal tablolarından satış yöntemi ile çıkarma faaliyetini gerçekleştirmiştir. 


\subsection{Metodoloji}

Bankaların etkinliklerinin ölçümünde literatür bölümünde de açıklandığı üzere genellikle veri zarflama analizi kullanılmaktadır. Veri zarflama analizinde verilen girdileri kullanarak sistemin en çok çıktıyı üretip üretemediği değerlendirilmektedir. Ancak, finansal piyasanın temel kurumu olan bankalar fon aracılığı yaparken bazı riskleri de üstlenmektedir ve etkinlik değerlendirmesinde bu risklerini azaltarak çıktı olarak ürettikleri krediler ve portföyleri maksimize etmeleri beklenmektedir. Ayrıca, son yıllarda bankalar sıklıkla risklerini azaltmak için takipteki kredi portföyünü Varlık Yönetim Şirketlerine satmaktadır. Bankaların bu satışlar sonrasında aktif kalitesi ölçümüne ilişkin en önemli oranlarından birisi olan Takipteki Krediler (Brüt) / Toplam Krediler rasyosunda bir düşüş (iyileşme) gerçekleşmektedir. Bu durumda, etkin bir banka mevcut personel, varlık ve mevduatını kullanarak maksimum kredi ve portföy üretirken aynı zamanda kredi ve portföy riskleri ile Takipteki Krediler (Brüt) / Toplam Krediler rasyosunu minimize edebilen banka olarak tanımlanabilir.

Veri zarflama yönteminde ancak mevcut çıktıların maksimize edilmesi söz konusu olmakta istenmeyen çıktılar olan riskleri göz ardı ederek değerlendirme yaptığı için bu çalışmada 1997 yılında Chung ve diğerleri tarafından geliştirilen, istenilen ve istenmeyen çıktıların birlikte oluştuğu durumu değerlendirmeye katan performans endeksi "uzaklık yönlü fonksiyon yaklaşımının" kullanılması uygun görülmüştür.

Uzaklık yönlü fonksiyon yaklaşımı 1997 yılında Chung ve diğerleri tarafından istenilen çıktıların maksimize edilmesi ve istenmeyen çıktıların ise minimize edilmesine dayanan bir etkinlik ölçütü olarak ortaya çıkarılmıştır.

$y \in R^{M} \mathrm{M}$ tane istenilen çıktıyı, $b \in R^{I}$ I tane istenmeyen çıktıyı ve $x \in R^{N}$ ise $\mathrm{N}$ adet girdi değerleri ifade edecek olursa istenmeyen çıktılarını azaltan şirketlere iyi performans verebilmek için Eşitlik 1'de verilen uzaklık yönlü fonksiyon teknolojik etkinlik için kullanılmıştır.

$\vec{D}_{0}(x, y, b ; g)=\sup \{\beta:(y, b)+\beta g \in P(x)\}$

Burada, g çıktıları ölçeklendiren yön vektörüdür. Bu çalışmada $g=(y,-b)$ olarak kullanılmaktadır. Bu durumda, girdiler sabit iken istenmeyen girdilerin azaltılması ancak istenen girdilerin artırılması durumunda uygun çözüm alanını oluşturacak kısıtlamalara sahip doğrusal programlama problemi aşağıda verildiği şekildedir.

$$
\begin{aligned}
& \vec{D}_{0}^{t}\left(x^{t, k}, y^{t, k}, b^{t, k} ; g=\left(y^{t, k},-b^{t, k}\right)\right)=\operatorname{Enb} \beta \\
& \text { s.t. } \sum_{k=1}^{K} z_{k} y_{k, m}^{t} \geq(1+\beta) y_{k, m}^{t}, m=1, \ldots, M \\
& \sum_{k=1}^{K} z_{k} b_{k, i}^{t} \geq(1-\beta) b_{k, i}^{t}, i=1, \ldots, I \\
& \sum_{k=1}^{K} z_{k} x_{k, n}^{t} \geq(1-\beta) x_{k, n}^{t}, n=1, \ldots, N \\
& z_{k} \geq 0, k=1, \ldots, K
\end{aligned}
$$

Yukarıdaki denklemlerde yer alan z yoğunluk değişkenidir. Burada sonuçta elde edilen beta değeri karar birimlerinin etkin olmama skorlarını göstermektedir. Beta değerlerinin sıfır olması bankaların etkin çalıştığı anlamına gelmektedir.

\section{BULGULAR VE TARTIŞMALAR}

Türk Bankacılık Sektöründe rekabetin artması ile birlikte bankalar bir taraftan etkinliğe önem verirken aynı zamanda risk yönetiminde de uluslararası düzenlemelere paralel olarak ciddi önlemler almaya başlamışlardır. Ancak her şeye rağmen kredilerin bir kısmının zamanında tahsil edilememesi ve bu nedenle temerrüde düşmesi kaçınılmaz olmaktadır. Bu durum da bankaların finansal tablolarda aktif kalitesini düşüren bir gösterge olarak karşımıza çıkmaktadır. Dünyadaki benzer örneklerine paralel olarak Ülkemizde de son yıllarda giderek yoğunlaşan işlemlerden birisi de bankaların aktif kalitelerini iyileştirmeye yönelik olarak çözüm üretemedikleri ya da çözüm üretmenin uzun zaman alacak olması nedeni ile yüksek maliyete neden olacağı vb gerekçelerle takipteki kredilerini Varlık Yönetim Şirketlerine satış işlemlerinin giderek artmasıdır. 
Aşağıda yer alan tabloda analiz kapsamında yer alan 23 bankaya ilişkin Takipteki Krediler (Brüt) / Toplam Krediler rasyosu yer almaktadır. Aynı zamanda takipteki kredilerinden satış yapan bankaların satış öncesi ve satış sonrası oranlarına da ayrıntılı olarak tabloda yer verilmiştir.

Tablo 2: Mevduat Bankaları Takipteki Krediler (Brüt)/Toplam Krediler Rasyosu Satış Öncesi ve Sonrası Karşılaştırma

\begin{tabular}{|c|c|c|c|c|c|c|c|c|c|c|c|c|c|c|c|c|}
\hline & \multicolumn{2}{|c|}{2008} & \multicolumn{2}{|c|}{2009} & \multicolumn{2}{|c|}{2010} & \multicolumn{2}{|c|}{2011} & \multicolumn{2}{|c|}{2012} & \multicolumn{2}{|c|}{2013} & \multicolumn{2}{|c|}{2014} & \multicolumn{2}{|c|}{2015} \\
\hline & $\mathrm{SS}^{1}$ & SÖ ${ }^{2}$ & SS & sö & SS & sö & SS & sö & SS & sö & SS & sö & SS & sö & SS & sö \\
\hline Sektör & 3,60 & 3,68 & 5,43 & 5,48 & 3,71 & 3,75 & 2,67 & 2,73 & 2,85 & 2,93 & 2,69 & 2,94 & 2,75 & 2,94 & 2,96 & 3,10 \\
\hline Banka 1 & 2,57 & 4,04 & 4,49 & 4,49 & 2,42 & 3,02 & 1,80 & 1,80 & 1,27 & 1,27 & 1,51 & 2,54 & 1,85 & 2,99 & 2,38 & 4,15 \\
\hline Banka 2 & 5,44 & 5,44 & 7,07 & 7,07 & 4,62 & 7,31 & 4,94 & 4,94 & 4,50 & 6,80 & 3,59 & 3,59 & 4,96 & 4,96 & 5,09 & 5,09 \\
\hline Banka 3 & 2,25 & 2,25 & 3,34 & 3,34 & 2,88 & 2,88 & 2,68 & 2,68 & 3,28 & 3,28 & 2,60 & 2,60 & 3,14 & 3,65 & 0,93 & 0,93 \\
\hline Banka 4 & 1,81 & 1,81 & 1,68 & 1,68 & 1,19 & 1,19 & 0,68 & 0,68 & 1,16 & 1,16 & 0,60 & 0,60 & 1,11 & 1,11 & 0,14 & 0,14 \\
\hline Banka 5 & 6,96 & 6,96 & 12,44 & 12,44 & 7,22 & 7,22 & 4,66 & 4,66 & 5,72 & 5,72 & 2,35 & 2,35 & 2,01 & 5,59 & 2,57 & 6,02 \\
\hline Banka 6 & 10,36 & 10,36 & 19,26 & 19,26 & 14,10 & 14,10 & 12,05 & 12,05 & 8,21 & 8,21 & 5,77 & 5,77 & 3,86 & 3,86 & 2,19 & 2,19 \\
\hline Banka 7 & 3,20 & 3,20 & 6,21 & 6,21 & 5,00 & 5,67 & 3,28 & 4,94 & 4,16 & 4,41 & 3,57 & 4,46 & 3,92 & 3,92 & 5,22 & 6,85 \\
\hline Banka 8 & 0,00 & 0,00 & 0,00 & 0,00 & 0,01 & 0,00 & 0,00 & 0,00 & 0,00 & 0,00 & 0,00 & 0,00 & 0,00 & 0,00 & 0,00 & 0,00 \\
\hline Banka 9 & 1,23 & 1,23 & 2,81 & 2,81 & 3,32 & 3,32 & 0,78 & 0,78 & 0,92 & 0,92 & 1,17 & 1,17 & 2,08 & 3,82 & 0,80 & 0,80 \\
\hline Banka 10 & 3,69 & 3,69 & 8,29 & 8,29 & 7,07 & 7,07 & 6,11 & 6,11 & 6,90 & 6,90 & 6,94 & 8,66 & 5,44 & 7,53 & 6,64 & 8,32 \\
\hline Banka 11 & 5,33 & 5,33 & 12,00 & 12,00 & 9,53 & 9,53 & 4,39 & 4,39 & 4,85 & 4,85 & 6,32 & 10,96 & 6,42 & 6,42 & 6,08 & 8,89 \\
\hline Banka 12 & 2,43 & 2,43 & 3,97 & 3,97 & 3,20 & 3,20 & 2,22 & 3,73 & 2,41 & 3,73 & 2,33 & 3,50 & 2,73 & 4,57 & 3,00 & 4,58 \\
\hline Banka 13 & 4,92 & 4,92 & 8,20 & 8,20 & 6,59 & 6,59 & 5,92 & 5,92 & 3,82 & 4,79 & 5,12 & 5,12 & 5,73 & 6,60 & 6,04 & 7,33 \\
\hline Banka 14 & 3,32 & 3,32 & 6,24 & 6,24 & 5,02 & 5,02 & 4,27 & 4,27 & 5,07 & 5,07 & 6,37 & 8,18 & 5,65 & 5,65 & 4,38 & 4,38 \\
\hline Banka 15 & 4,40 & 4,40 & 6,26 & 6,26 & 4,36 & 4,36 & 5,54 & 5,54 & 1,98 & 1,98 & 0,79 & 0,79 & 0,85 & 0,85 & 1,51 & 1,51 \\
\hline Banka 16 & 2,60 & 2,60 & 4,68 & 4,68 & 4,00 & 4,00 & 2,68 & 3,73 & 3,40 & 3,40 & 2,62 & 2,62 & 2,84 & 4,07 & 6,10 & 6,10 \\
\hline Banka 17 & 2,37 & 3,23 & 4,76 & 5,07 & 3,06 & 3,06 & 2,83 & 2,83 & 2,17 & 2,17 & 2,28 & 2,28 & 2,47 & 3,00 & 2,32 & 3,40 \\
\hline Banka 18 & 1,96 & 1,96 & 2,33 & 2,33 & 1,49 & 1,49 & 1,21 & 1,21 & 2,88 & 2,88 & 2,18 & 2,18 & 1,91 & 1,91 & 1,68 & 1,68 \\
\hline Banka 19 & 2,48 & 2,48 & 4,50 & 4,50 & 2,99 & 2,99 & 1,83 & 1,83 & 2,30 & 3,67 & 2,14 & 3,87 & 2,46 & 4,48 & 2,77 & 4,46 \\
\hline Banka 20 & 4,84 & 4,84 & 5,14 & 5,14 & 3,97 & 3,97 & 2,97 & 2,97 & 2,97 & 2,97 & 2,65 & 2,65 & 3,64 & 3,64 & 3,14 & 3,14 \\
\hline Banka 21 & 4,61 & 4,61 & 5,73 & 6,16 & 3,75 & 4,26 & 2,17 & 3,79 & 1,89 & 1,89 & 1,65 & 1,65 & 1,55 & 2,61 & 2,03 & 3,32 \\
\hline Banka 22 & 4,77 & 4,77 & 6,13 & 6,13 & 5,05 & 5,05 & 3,76 & 3,76 & 4,00 & 4,00 & 4,07 & 4,07 & 3,80 & 3,80 & 3,92 & 3,92 \\
\hline Banka 23 & 4,43 & 5,76 & 6,82 & 7,01 & 3,54 & 6,05 & 3,07 & 3,07 & 3,33 & 4,26 & 3,70 & 4,80 & 3,55 & 4,81 & 4,12 & 4,12 \\
\hline
\end{tabular}

Kaynak: - SS değerleri https://www.tbb.org.tr/tr/bankacilik/banka-ve-sektor-bilgileri/istatistiki-raporlar/59 adresinden alınmıştır.

- SÖ değerleri VYŞ'lerin, finansal raporlarından, ilgili bankaların Kamuyu Aydınlatma Platformu'na iletmiş olduğu açıklamalardan, ilgili

bankaların finansal raporlarından derlenerek tarafımızca hesaplanmıştır.

Takipteki kredilerini Varlık Yönetim Şirketlerine satan bankaların satış işlemi ile rasyolarında sağladığı iyileşme oransal olarak aşağıdaki tabloda yer almaktadır:

\footnotetext{
${ }^{1}$ SS: Takipteki kredilerin Varlık Yönetim Şirketlerine satışından sonra hesaplanan ve kamuoyuna açıklanan rasyolar

${ }^{2}$ SÖ: Takipteki kredilerin Varlık Yönetim Şirketlerine satışından öncesine ait olan, gerçek takipteki kredi rasyoları.
} 
Tablo 3: Varlık Yönetim Şirketlerine Satış Yapan Bankaların Takipteki Krediler (Brüt)/Toplam Krediler Rasyosunda Sağlanan Oransal İyileşme

\begin{tabular}{|c|c|c|c|c|c|c|c|c|}
\hline$\%$ & 2008 & 2009 & 2010 & 2011 & 2012 & 2013 & 2014 & 2015 \\
\hline Sektör & 2,2 & 1,0 & 1,1 & 2,2 & 2,7 & 8,5 & 6,5 & 4,5 \\
\hline Banka 1 & 36,4 & & 19,9 & & & 40,6 & 38,1 & 42,7 \\
\hline Banka 2 & & & 36,8 & & 33,8 & & & \\
\hline Banka 3 & & & & & & & 14,0 & \\
\hline Banka 5 & & & & & & & 64,0 & 57,3 \\
\hline Banka 7 & & & 11,8 & 33,6 & 5,7 & 20,0 & & 23,8 \\
\hline Banka 9 & & & & & & & 45,5 & \\
\hline Banka 10 & & & & & & 19,9 & 27,8 & 20,2 \\
\hline Banka 11 & & & & & & 42,3 & & 31,6 \\
\hline Banka 12 & & & & 40,5 & 35,4 & 33,4 & 40,3 & 34,5 \\
\hline Banka 13 & & & & & 20,3 & & 13,2 & 17,6 \\
\hline Banka 14 & & & & & & 22,1 & & \\
\hline Banka 16 & & & & 28,2 & & & 30,2 & \\
\hline Banka 17 & 26,6 & 6,1 & & & & & 17,7 & 31,8 \\
\hline Banka 19 & & & & & 37,3 & 44,7 & 45,1 & 37,9 \\
\hline Banka 21 & & 7,0 & 12,0 & 42,7 & & & 40,6 & 38,9 \\
\hline Banka 23 & 23,1 & 2,7 & 41,5 & & 21,8 & 22,9 & 26,2 & \\
\hline
\end{tabular}

Kaynak: Tablo2'deki veriler kullanılarak tarafımızca hesaplanmıştır.

Tablodan da görüleceği üzere takipteki kredilerini Varlık Yönetim Şirketlerine satan bankaların Takipteki Krediler (Brüt)/Toplam Krediler rasyolarındaki iyileşme \%1-\%64 aralığındadır.

Bankaların etkinlik değerlendirmesi yapılırken, esas olarak bir taraftan minimum girdi ile maksimum çıktı hedeflenirken, diğer taraftan da elde edilen çıktıların minimum risk üstlenilerek elde edilmesi gerekmektedir.

Bu çerçevede, etkinlik değerlendirmesinde aynı etkinliğe sahip bankalar için riski daha düşük olan bankalar daha etkin olarak dikkate alınmıştır. Bir diğer yaklaşım ise aynı risk düzeyinde olan bankalar için daha yüksek etkinlik sağlayan bankalar performans açısından ön plana çıkmıştır.

Analiz kapsamında yer alan 23 adet bankanın 16 adedi 2008-2015 dönemi içinde takipteki kredilerinden bir kısmını Varlık Yönetim Şirketlerine satmışlardır. Kalan 7 banka ise bu dönemde satış yapmamıştır.

Bu çerçevede 2008-2015 dönemi içinde analize alınan 23 bankadan, takipteki kredilerini hiç satmayan bankaların üstlendikleri riskler de dikkate alınarak yapılan etkinlik değerlendirmesinde doğal olarak bir farklılaşma olmamıştır.

Diğer taraftan, aynı analizde, takipteki kredilerini varlık yönetim şirketlerine satmaları sonucunda oluşan Takipteki Kredi (Brüt) / Toplam Kredi rasyosu risk göstergelerinden birisi olarak dikkate alınmış ve analiz sonuçları bu çerçevede elde edilmiştir. Daha sonra ise aynı bankalar için takipteki kredilerini varlık yönetim şirketlerine satmadan önceki gerçek Takipteki Kredi (Brüt) / Toplam Kredi rasyosu risk göstergelerinden birisi olarak dikkate alınmış ve analiz tekrarlanmıştır.

Analiz sonucunda elde edilen fonksiyon değerleri Tablo 4'de yer almaktadır. 
Tablo 4: 2008-2015 Yılları Arasında Bankaların Etkinliklerine illişkin Uzaklık Yönlü Fonksiyon Değerleri Satış Öncesi ve Sonrası Karşılaştırması

\begin{tabular}{|c|c|c|}
\hline & Satış Öncesi Etkinlik Skoru & Satış Sonrası Etkinlik Skoru \\
\hline Banka 1 & 0,000 & 0,000 \\
\hline Banka 2 & 0,000 & 0,000 \\
\hline Banka 3 & 0,035 & 0,030 \\
\hline Banka 4 & 0,333 & 0,333 \\
\hline Banka 5 & 0,000 & 0,000 \\
\hline Banka 6 & 0,361 & 0,361 \\
\hline Banka 7 & 0,024 & 0,022 \\
\hline Banka 8 & 0,000 & 0,000 \\
\hline Banka 9 & 0,000 & 0,000 \\
\hline Banka 10 & 0,000 & 0,000 \\
\hline Banka 11 & 0,166 & 0,165 \\
\hline Banka 12 & 0,000 & 0,000 \\
\hline Banka 13 & 0,000 & 0,000 \\
\hline Banka 14 & 0,000 & 0,000 \\
\hline Banka 15 & 0,000 & 0,000 \\
\hline Banka 16 & 0,000 & 0,000 \\
\hline Banka 17 & 0,000 & 0,000 \\
\hline Banka 18 & 0,000 & 0,000 \\
\hline Banka 19 & 0,000 & 0,000 \\
\hline Banka 20 & 0,000 & 0,000 \\
\hline Banka 21 & 0,000 & 0,000 \\
\hline Banka 22 & 0,000 & 0,000 \\
\hline Banka 23 & 0,000 & 0,000 \\
\hline
\end{tabular}

Tablo 4'de yer alan taralı olmayan bankalar 2008-2015 yılları arasında takipteki kredi portföyünden hiç satış yapmayan bankalardır. Bu bankalar yukarıdaki tabloda yer alan Banka 4, Banka 6, Banka 8, Banka 15, Banka 18, Banka 20 ve Banka 22'dir. Bu bankaların etkinlik değerlerinde bir farklılaşma olmaması doğaldır.

Sözkonusu tabloda yer alan ve fonksiyon değerleri taralı olan bankaların 2008-2015 yılları arasındaki etkinlik değerlerinin bazılarında farklılaşma olurken bazılarında farklılaşma olmadığı görülmüştür.

Etkinlik değerleri farklılaşmayan bankalar, hem satış öncesi hem de satış sonrası etkin değere sahip olan bankalardır. Bu bankalar Banka 1, Banka 2, Banka 5, Banka 9, Banka 10, Banka 12, Banka 13, Banka 14, Banka 16, Banka 17, Banka 19, Banka 21 ve Banka 23'dür.

Etkinlik değeri farklılaşan bankalar ise takipteki kredilerini sattıktan sonraki değerleri dikkate alınarak yapılan analizde etkin olmayan bankalar olarak karşımıza çıkanlar olup, gerçek Takipteki Kredi (Brüt) / Toplam Kredi (Varlık Yönetim Şirketlerine satış yapmadan önceki rakamlarına göre) rasyosu dikkate alınarak analiz edildiğinde de etkinsiz fonksiyon değerine sahip olmaktadır.

Nitekim resmi finansal tablo verileri ile analiz yapıldığında etkinsiz çıkan 3 adet banka, Banka 3, Banka 7 ve Banka 11'in etkinlik skorlarında satış öncesine ait gerçek takipteki kredi rasyosu dikkate alındığında değişiklik olmuştur.

Aşağıdaki tabloda takipteki kredilerini Varlık Yönetim Şirketlerine satan bankaların etkinlik skorlarındaki iyileşmeler yer almaktadır. 
Tablo 5: Takipteki Kredilerini Varlık Yönetim Şirketlerine Satan Bankaların Etkinlik Skorlarındaki İyileşmeler

\begin{tabular}{|c|c|c|c|}
\hline & Satı̧ Öncesi Etkinlik Skoru & Satış Sonrası Etkinlik Skoru & $\begin{array}{c}\text { Etkinlik Skorunda İyileşme } \\
\text { Oranı \% }\end{array}$ \\
\hline Banka 1 & 0 & 0 & 16,67 \\
\hline Banka 2 & 0 & 0,03 & \\
\hline Banka 3 & 0,035 & 0 & 9,09 \\
\hline Banka 5 & 0 & 0,022 & \\
\hline Banka 7 & 0,024 & 0 & 0,61 \\
\hline Banka 9 & 0 & 0 & \\
\hline Banka 10 & 0 & 0,165 & \\
\hline Banka 11 & 0,166 & 0 & \\
\hline Banka 12 & 0 & 0 & \\
\hline Banka 13 & 0 & 0 & \\
\hline Banka 14 & 0 & 0 & \\
\hline Banka 16 & 0 & 0 & \\
\hline Banka 17 & 0 & 0 & \\
\hline Banka 19 & 0 & 0 & 0 \\
\hline Banka 21 & 0 & 0 & \\
\hline Banka 23 & 0 & 0 & \\
\hline
\end{tabular}

Tablodan da görüleceği üzere:

- Banka 1, Banka 2, Banka 5, Banka 9, Banka 10, Banka 12, Banka 13, Banka 14, Banka 16, Banka 17 Banka 19 Banka 21 ve Banka 23 takipteki kredilerini Varlık Yönetim Şirketlerine satış öncesinde yapılan analiz çerçevesinde etkin çıkmış olup, satış sonrasında da etkin olduğu sonucu elde edilmiştir. Bu kapsamda etkin çalışan bankalarda takipteki kredilerin Varlık Yönetim Şirketlerine satışı sonrasında finansal tablolarda yapılan aktif kalitesinin iyileştirilmesinin bir etkisi olmadığı ifade edilebilir.

- Banka 3 Banka 7 ve Banka 11 ise takipteki kredilerini Varlık Yönetim Şirketlerine satmadan önceki verileri ile analiz edildiğinde düşük etkinlikte çıkan bankalardır. Satış sonrası verileri ile yapılan analiz sonucunda yine düşük etkinlikte çıkmış ancak etkinsizlik seviyesinde sözkonusu satışların olumlu etkisi olduğu görülmüştür.

\section{SONUÇ}

Ülke ekonomisinin itici konumundaki bankacılık sektöründe etkinlik artışı ile birlikte risklerin minimum seviyede üstlenilmesi ekonomik büyüme ve kalkınma açısından büyük önem taşımaktadır. Finansal tablolarda görünen riskler bankalarla işlem gerçekleştiren / gerçekleştirecek taraflar açısından çok önemlidir. Çünkü karar alıcılar bankalarla işlem aşamasında ya da gerçekleştirilen işlemlerinin sürdürülebilirliğine karar verme aşamasında bir taraftan sağlayacağı kazancı diğer taraftan da sözkonusu bankanın risk seviyesini dikkate almaktadır. Bu çerçevede kararlarını veren yatırımcılar açısından finansal tablolardan okunabilen riskler kayda değer niteliktedir.

Bankaların aktif kalitesine ilişkin en önemli göstergelerden birisi Takipteki Kredi (Brüt) / Toplam Kredi rasyosudur. Rasyonun düşük olması bankanın hem müşteri seçiminde doğru karar verdiğini, hem de kredi verildikten sonraki izleme yöntemlerinin sağlıklı olduğu konusunda fikir vermektedir. Bu çerçevede aktif kalitesi iyi olan bankalar bir taraftan daha düşük maliyetle kaynak bulabilirken, diğer taraftan da rakipleri gibi aynı getiri seviyesinde kullandırım yapsalar bile rakiplerine göre maliyet getiri farkına ilişkin marjın açılması nedeni ile karlılıkları yükselmektedir.

Bu çalışmada yapılan analizler sonucunda, takipteki kredilerini Varlık Yönetim Şirketlerine satan bankalardan:

- Bir taraftan risklerini azaltırken diğer taraftan da verimli çalışanlarda, sözkonusu satış işlemlerinin verimliliğe bir katkısı olmadığı görülmüştür.

- Ancak satış öncesi düşük etkinlik seviyesinde çıkan bankalarda, sözkonusu satış işleminin bir miktar iyileşme sağladığı gözlenmiştir. 
Sonuç olarak etkin çalışan bankalarda takipteki kredilerin varlık Yönetim Şirketlerine satışının etkinliğe yansıması gözlenmemiş iken, etkin olmayan bankalarda sözkonusu satışların bu bankaların etkinsizlik seviyesinde olumlu yönde iyileşme sağladığı görülmüştür.

\section{KAYNAKLAR}

Akbalık, M. ve Sırma, İ. 2013, Türkiye'de Yabancı Bankaların Etkinliği; “Veri Zarflama Analiz Uygulaması, Finansal Araştırmalar ve Çalışmalar Dergisi", 4(8), pp. 1-16.

Babuşçu, Ş. ve Hazar, A. 2013, Varlık Yönetim Şirketlerine Satılacak Takipteki Krediler İçin Değerleme Varsayımsal Bir Yaklaşım, “Muhasebe Bilim Dünyası", 15(1), pp. 153-175.

Budak, H. 2011, Veri Zarflama Analizi ve Türk Bankacılık Sektöründe Uygulaması, Fen Bilimleri Dergisi, 23(3), 95-110.

Demir, N., Mahmud, S.F., Babuşcu, Ş. 2005, The Technical Inefficiency Effects of Turkish Banks after Financial Liberalization, "The Developing Economies" , "43-3", pp. 396-411, Ekim.

Eken, M. H. ve Kale, S., 2013, Evaluating the Efficiency of Turkish Banks: A Risk and Profitability Approach. JCC:" The Business and Economics Research Journal". 6(1), pp.53-68.

Er, M. ve Uysal M. 2012, Türkiye'deki Ticari Bankalar ve Katılım Bankalarının Karşılaştırmalı Etkinlik Analizi: 2005-2010 Dönemi Değerlendirmesi, “Atatürk Üniversitesi Iktisadi ve Idari Bilimler Dergisi”, 26(3), pp.365-387.

Gör, Y. ve Tekin, B. 2014, Asset Management Companies: A Sector Analysis in Turkey, "International Finance and Banking Conference", FI BA. 2014 .

Isık, I. ve Hassan, M. K.H. 2002, Technical, Scale and Allocative Efficiencies of Turkish Banking Industry. "Journal of Banking and Finance", 26, pp.719-766.

İlseven, N. 2002, Varlık Yönetim Şirketleri ve Türkiye Finans Sektörü, BDDK Bankacılık Sektörünün Yeniden Yapılandırılması Programı, İstanbul, 26.07.2002.

Küçükbay, F. ve Dilek D. 2003, Avrupa Birliği'ne Uyum Sürecinde Türkiye'de Finansal Yeniden Yapılandırma Uygulamaları: İstanbul Yaklaşımı ve Varlık Yönetim Şirketi, “Mali Çözüm Dergisi”, Sayı:63, pp.143-155.

Mesutoğlu, B. 2001, Sorunlu Aktiflerin Varlık Yönetimi Şirketlerince Tasfiyesi - Ülke Örnekleri, “MSDP Çalışma Raporları”, BDDK: 2001/3.

Özkan-Günay, E. N. 2012, Risk Incorporation and Efficiency in Emerging Market Banks During the Global Crisis: Evidence from Turkey, 2002-2009, "Emerging Markets Finance and Trade", 48(5), pp.91-102.

Sakar, B. 2004, “Banka Yapılandırma Sürecinde Varlık Yönetim Şirketleri Seçilmiş Ülkeler ve Türkiye Uygulaması”, Yayımlanmamış Doktora Tezi. İstanbul: Marmara Üniversitesi Bankacılık ve Sigortacılık Enstitüsü.

Selimler, H. 2006, Türk Bankacılık Sektöründe Sorunlu Kredilerin Varlık Yönetim Şirketlerince Tasfiyesi, Seçilmiş Ülkeler ve Türkiye Uygulaması, Yayımlanmamış Doktora Tezi. İstanbul: Marmara Üniversitesi Bankacılık ve Sigortacılık Enstitüsü.

Sezgin-Alp, Ö. ve Hazar, A. 2015, Banka Performanslarının Ölçümünde Uzaklık Yönlü Fonksiyon Yaklaşımı, "Maliye Finans Yazıları", 103, pp.157-174.

Torun, N. K. ve Özdemir, A. 2015, Türk Bankacılık Sektörünün 2008 Küresel Finansal Krizi Sürecinde Veri Zarflama Analizi Ile Etkinlik Analizi, "Selçuk Üniversitesi Sosyal Bilimler Enstitüsü Dergisi", 33, pp.129-142.

Yayar, R. ve Karaca, S. (2014), Efficiency Analysis in Turkish Banking Sector, "Niğde Üniversitesi iiBF Dergisi”, 7(2), pp.1-15.

www.tbb.org.tr 